\title{
NOTES ON COSTA RICAN BIRDS
}

\author{
BY LEE S. CRANDALL, \\ Assistant Curator of Birds.
}

\section{PART I.-INTRODUCTION.}

After a nine days' journey on the United Fruit Company's steamer "Calamares," the writer, accompanied by T. Donald Carter as assistant, arrived at Port Limon, Costa Rica, on March 30,1914 . Our object was the gathering of living specimens for the collections of the New York Zoological Society, and when, after a stay of six weeks, we re-embarked on the "Calamares" with something over three hundred creatures, embracing all of the vertebrate classes, in our care, we felt that our efforts had not been in vain.

There was some delay in entering our luggage and it was only after a wait of several days, entailing a trip to the lovely capital city, San José, that this was finally accomplished. We were then free to repair to our proposed collecting ground, in the vicinity of Guápiles, a small village at the terminus of the Old Line Railroad, fifty-nine miles northwest of Port Limon. Here we found reasonably comfortable quarters in a small hotel conducted in connection with the general store.

The representatives of the United Fruit Company were uniformly courteous, and without their co-operation, the work would have been very difficult indeed. My thanks are due especially to Mr. W. E. Mullins, General Manager, Mr. Wilson of Guápiles, and Mr. Doswell of Port Limon. I am grateful also to Senor Juan Quesada, Senor Rafael Tristán and Mr. W. F. Milkevitch, of Kiew, Russia, all of whom contributed much to the success of the expedition.

\section{PART II.-ECOLOGICAL CONDITIONS.}

Guápiles lies on the northern slope of the Volcan Turrialba, at an elevation of about eight hundred feet. Rainfall is of almost daily occurrence throughout the year, the seasons not 
being strongly demarcated, as they are in the highlands. There are occasional periods of greater precipitation, and at these seasons there may be several days of continuous rainfall, without intermission.

The country about Guápiles is fairly level, with a gentle northward slope. Once the greatest of Costa Rican banana districts, its usefulness in that direction was destroyed by the inroads of a blight which destroyed the growing fruit. When it appeared useless to combat this trouble longer, the plantations were levelled and the land given over to cattle producing. The pastures are of considerable extent, running back on both sides of the railroad from one to two miles, where the forest commences.

The pastures or potreros, are very rough in character, constant effort being necessary to keep the bush from reclaiming its own. Each stream is marked by a line of trees and bushes, often extending into bits of very tangled jungle, and scattered trees are numerous. Each pasture is divided from the next by fences of barbed wire. As dead posts are unable to withstand for long the continual rain, small stakes of a softwood tree are used. These stakes begin to sprout almost at once and soon reach a height of fifteen to twenty feet. They thus form permanent fence-posts and their thick foliage provides the birds with excellent hiding and nesting places.

Bird life at this altitude is exceedingly varied, but individuals, at least at the time of our visit, were not nearly so abundant as we had been led to expect. At this season, of course, their numbers were at their lowest ebb, as nesting was just commencing, and few young birds were as yet on the wing. The adults were paired and scattered, and as there was very little fruit ripe at the time, there was no concentration.

A sharp line was noticeable between the birds of the open and of the jungle, neither group usually entering the domain of the other. The most typical species of the potreros were Parrots and Parrakeets (Conurus finschi, C. aztec and Pionus senilis); the Tanagers (Rhamphocoelus passerinii, Thraupis cana cana, T. palmarum melanoptera, Tangara larvata larvata and Euphonia luteicapilla); Flycatchers (Myiozetetes texensis 
texensis, $M$. granadensis, Legatus albicollus, Tyrannus albicollis satrapa, Pitangus sulphuratus derbianus and Megarhynchus pitangua) ; Bonaparte Tawny Robin (Planesticus grayi casius); six of the Fringillidx (Saltator magnoides medianus; Arremonops conirostris richmondi; Sporophila morelleti; S. corvina; Tiaris olivacea pusilla and Volatinia jacarini splendens); the Sooty Synallaxis (S. pudica nigrifumosa); and of course the two Vultures (Catharista urubu brasiliensis and Cathartes aura aura). The great Cacique (Gymnostinops montezuma) is of frequent occurrence, its colonies usually being found in open places rather than in the forest.

On entering the jungle, the bird life changes at once. Antthrushes (Formicariidx) and Woodhewers (Dendrocolaptidx) creep among the bushes or flit from trunk to trunk. Trogons (Chrysotrogon caligatus, Trogonurus pueila and Curucujus massena), Black-chinned Jacamars (Galbula melanogenia); Puff-birds (Bucconid $x$ ) and Cotingas (Cotingidæ) are often seen. Motmots (Momotidx) are represented here by three species, but careful search did not disclose a single specimen.

There, are of course, many mammals. A small deer (Odocoileus costaricensis) is abundant, as are Pecarries (Tayassu tajacu), Agoutis (Dasiprocta) and Spotted Cavies (Coelogenys paca). A jaguar was killed during our stay at Guápiles. There are Raccoons (Procyon lotor fernandezi), Opossums (Didelphys and Marmosa) and Coatis (Nasua rufa), two species of squirrels (Sciurus) and at least two monkeys, the Geoffroy Spider (Ateles geoffroyi) and a small Capuchin (Celius hypoleucus).

Snakes were not abundant and few species were noted, among them Spilotes corais, a coral (Elaps), a coral-like species (Leptognathus), a Tree-snake (Himantodes), Fer-de-Lance (Lachesis lanceolatus) and a striped snake (Dromicus). Lizards of several species were abundant, especially a small Anolis, which lived in the shrubbery everywhere, leaping with froglike agility.

The great Marine Toads (Bufo agua) were not nearly so numerous as observed by the writer in British Guiana, and were never abundant. A beautiful little red frog with blue 
legs (Dendrobates typographus typographus) and a tiny treetoad (Hylotes underwoodi) were found in the forest. Goodsized tree-toads (Smilisca baudini) were fairly common about Guâpiles, trilling nightly from the surrounding potreros. A large green frog (Rana chyrosprasina) inhabited the banks of the streams, but was very shy and difficult to collect.

The country is well drained, the streams being numerous and very swift. One small brook, not more than three feet wide, near our headquarters, contained numerous fishes-small eels and catfishes, at least three species of Cichlids, Astyanax xneus costaricensis, and six species of the Pociliidæx (Rivulus isthmensis, mollienisia sphenops tropica, Alfare cultratum, Priapichthys annectens, Pœciliopsis pittieri and Brachyrhaphis umbratilis).

Insects were not numerous. Mosquitoes were troublesome only during the early morning, but bete rouge, ticks and a small black fly were plentiful enough.

As the object of the expedition was the collection of living specimens, few skins were made, so these notes must be confined to those birds which we were able to observe or capture without the use of guns. No attempt has been made to give a list of species seen, as this ground already has been admirably covered by several writers, chiefly Robert Ridgway ${ }^{1}$ and M. A. Carriker, Jr., ${ }^{2}$ and mention is made only of those birds concerning which some observation was made.

\section{PART III.-NOTES ON THE BIRDS.}

April 4, 1914-May 10, 1914.

\section{Cresciscus cinereiceps (Lawr.). Ashy-Headed RaIL.}

This tiny rail was abundant about Guápiles, being found in pairs wherever the ground had the slightest tendency toward marshiness. Its call-note is a sharp cackling, strikingly like that of Synallaxis pudica nigrifumosa... The birds were breeding and on April 9, 1914, a nest was found. It was globular, about six inches in diameter and built of narrow-leaved grasses, the entrance hole being at the side. It was placed in a small clump of grass, about six inches from the ground, in the center of a

1 Ridgway, Robert, Birds of Middle \& North America.

${ }^{2}$ Carriker, Jr., M. A. An Annotated List of the Birds of Costa Rica, including Cocos Island. 
diminutive marsh. The nest contained three eggs, creamy white, lightly blotched with pale brownish. On the following day the female was flushed from the nest, which was found to contain a single downy chick, the others perhaps having joined the father.

The young bird was clothed in thick black down, the feet and tarsi being of the same color. The beak was pure white, with a small black mark at each side of the lower mandible. The iris was dark brown.

A few days later, an adult bird was seen in a small patch of brush. When pursued it attempted to hide under some leaves and was caught by hand without difficulty.

\section{Asarcia variabilis (Linn.). MEXICAN JACANA.}

Not abundant about Guápiles, conditions there not being suitable. A single specimen, in the white-breasted immature plumage, was seen in a marshy pasture. It was not shy, and flew up silently when disturbed.

\section{Ajaia ajaja (Linn.). Roseate SpoonbiLl.}

Although abundant along the Pacific side of Costa Rica, this bird seems to be uncommon on the Carribean coast. A single bird, not quite adult, was taken in a swamp about four miles north of Guápiles.

\section{Sarcoramphus papa (Linn.). KING VUltURE.}

We had been led to believe that King Vultures were both shy and rare in Costa Rica, but subsequent observations proved this not to be the case. Soon after our arrival we noticed a pair sailing overhead in company with a cloud of Black Vultures (Catharista urubu brasiliensis). A few days later, we came across a dying calf, surrounded by a great number of the later birds, not more than one hundred yards from our headquarters. A bullet soon ended its misery. Next morning, the carcass was untouched, although Black Vultures were in constant attendance, and on the following day a King Vulture in dark plumage was sitting on it. The bird took a leisurely flight when ap- 
proached and examination showed the carcass undisturbed. The next day, three days after the death of the calf, four Kings, two adult males, one immature male and a female were feeding. These birds stayed about all day and were not at all shy, permitting persons to approach within one hundred feet. They devoured a great part of the carcass, and finally took themselves off, leaving the remainder to the greedy Blacks, which had been standing about at a respectful distance.

\section{Catharista urubu brasiliensis (Bonap.) SOUTH AMERICAN}

\section{BLACK VULTURE.}

This is the common vulture of Costa Rica. It is abundant everywhere, perching on the houses, selecting the tid-bits from the wagons of city refuse collectors, quarreling with dogs and poultry over morsels in the streets and industriously following its mission as general scavenger.

It is customary to stretch the hides of freshly killed cattle in accessible places and on several occasions vultures were noted in the act of stripping them of bits of fat and flesh, apparently doing so without injury to the hide.

It is of interest to note that the calf referred to under Sarcoramphus papa was dead three days before a really serious attack was made upon it. When it was first discovered, although not quite dead, the birds had removed its tail and made small incisions at various parts of its body. As soon as it was dead the eyes were extracted, but after that it remained untouched until the third day, when it was quickly devoured. This would seem to indicate that the birds were unable to penetrate the animal's hide until decomposition had softened it considerably. They hold the King Vultures in great awe, the coming of one of these great birds being the signal for the withdrawal of its meaner relatives.

On another occasion a King and a great number of Blacks were noticed perched on and about an isolated shed in a back potrero.... Investigation showed the shed to contain a quantity of fat, cut in strips and hung up to dry. The walls of the shed were formed by slats, the apertures being so narrow as to make the inside too dark to permit the contents to be seen 
from the outside. It had not been in use for some weeks, so the birds were not in the habit of finding food there, and it seems most probable that they had been guided to the spot by the slight sense of smell which these birds seem able to exercise at short distances.

\section{Cathartes aura aura (Linn.). NORTH AMERICAN TURKEY VULTURE.}

It is curious to note that while the Black Vultures are of the South American form, the Turkey Vultures belong to the same subspecies as those of North America. They are not abundant in Costa Rica, more than a pair seldom being seen at one time. They rarely stay about slaughter houses and similar places after the habit of the Blacks, but are usually seen alone, prowling about the potreros... They were shy and seemed to be in fear of the Blacks, perhaps because of the superior numbers of the latter.

\section{Nyctidromus albicollis albicollis (Gmel.). CUIEJo.}

This is the only common Goat Sucker about Guápiles. In the daytime, specimens were frequently disturbed as they sat on or near the ground, and at night their calls resounded from all sides.

On April 19th, three nests of this species were discovered in some open brush along an abandoned tramway. Two were about twenty-five feet apart and the other about one hundred feet distant. Each contained two pale brownish eggs, blotched with chocolate; all were fresh. One set was deposited in the hollow of a great, dried leaf; another between several smaller leaves and the third on the ground beside a large stone. No other nests were found during the entire trip and as there appeared to be nothing to distinguish this particular locality from the surrounding country, their occurrence there seems a curious coincidence.

Chrysotrogon caligatus (Gould). GARTEREd Trogon.

This is the most abundant Trogon about Guápiles. It is met with in the bits of bush along streams and in the pastures 
and may also be seen in the forest itself. It seems also to have a fondness for banana plantations, where several were seen. They are easily located by their call, a high pitched monotone resembling "toot, toot, toot-toot," rapidly repeated. This call was given alike by male, female and young, no difference being distinguishable.

This bird is almost entirely fearless and is easily approached. It is usually seen low in the trees. It was often noticed hawking for insects, which it caught with great dexterity. It feeds also on berries, which it plucks while on the wing.

On April 12th, a young bird, apparently about two weeks old, was found perched in a tangle of bushes near a banana plantation. On the following day another, and on the next a third, were taken near the same place. They were similar in size and appeared to be from the same nest. Only one pair of adults had been seen in the vicinity, which lends strength to this supposition. Unfortunately the nesting site could not be located. Although the youngsters were able to fly, the parents were evidently still caring for them, for when one was brought to the vicinity in a cage, the mother came at once to feed it.

\section{Curucujus massena (Gould). Massena Trogon.}

This bird was less abundant than caligatus and less easily approached. The brilliant red abdomen is a conspicuous identification mark, although even then it is not always easily seen among thick foliage. It keeps higher in the trees than caligatus.

The note of this species is a series of slow, guttural clucks very strikingly galline in sound, and resembling that of caligatus only in the method of delivery. Males only were heard calling.

\section{Trogonurus puella (Gould). JALAPA TrogON.}

Two specimens only of this species, male and female, were observed. These birds were seen in the jungle near the Rio Toro Amarillo, about four miles south of the railroad, at an altitude considerably below the usual range of this species.

When first noticed, the birds were feeding on the fruit of a palm, about fifteen feet high. When disturbed they perched 
not far from the ground providing an excellent opportunity for observation. They were male and female and busily engaged in what appeared to be courtship manoeuvres. The voice of this species is intermediate between those of Curucujus massena and Chrysotrogon caligatus, in every point-tone, volume and time. The notes of the male are slightly higher and clearer than those of the female. The former would start off with his " $k u-k u-k u-k u$," raising his tail high over his back, but not spreading it. Sometimes he ducked his head and slightly opened his wings. The female would at once respond, raising her head and calling her more guttural "kuk-kuk-kuk" but not raising the wings or ducking. There was an evident attempt at alternation, but sometimes one would not wait for the other to finish and often they became so mixed that both were calling at once. This seemed an almost endless performance. Sometimes the birds sat side by side, their feathers touching, at others as much as ten feet separated them. At intervals the male would make short flights to a distance of fifty or one hundred feet. At these times he was silent. Soon he would return, flying very swiftly, with a loud buzzing of wings, to renew his love song.

\section{Crotophaga sulcirostris Swains. GRoove-BILled ANI.}

Although the country about Guápiles is largely given to stock breeding, Anis were not nearly so numerous as this species and $C$. ani have been observed in other countries. A few are usually in attendance on the cattle but they are far from abundant, as compared with former experiences.

There has been much controversy concerning the nesting habits of these birds. So much evidence has been advanced to demonstrate a communal system, under which several females lay in a single nest, that there is no denying the fact. This habit is not, however, invariable. Near our headquarters was a small orange tree, a favorite nesting place throughout the tropics, the sharp spines affording perfect protection. Here a pair of Anis had built their nest of sticks and were incubating. The female was first seen on the nest on April 2nd. Other Anis were in the vicinity, but we watched carefully day after day, and no other was ever seen in the tree. If ever a strange bird 
approached, the male of the nesting pair attacked it fiercely, driving it off. When the young birds, three in number, finally left the nest, they were guarded carefully by the two parents, who watched them assiduously and did not permit the approach of any other bird. Later another pair, accompanied by two youngsters, was seen catching insects in some long grass. Whether or not this is the usual nesting habit of Crotophaga sulcirostris in Costa Rica I cannot say, but these birds, at least, were paired in orthodox bird fashion.

\section{Campephilus guatemalensis guatemalensis (Hartl.).}

\section{GUATEMALAN IVORY-BILLED WOODPECKER.}

A young bird of this species, apparently about three weeks old, was collected on May 5th. It was able to fly but was quite fearless and was caught with no difficulty. The nest was not seen.

Synallaxis pudica nigrifumosa (Lawr.). Sooty Synallaxis.

This little Oven-bird is one of the most characteristic species about Guápiles. Wherever there is thick, tangled undergrowth along streams or in the potreros, its harsh, rail-like notes are certain to be heard. Many characteristic nests were found. They are usually from two to six feet from the ground in a clump of bushes. The entire structure is of course sticks, the nest being about a foot in length and somewhat less in diameter. It is domed at the top, with a long entrance tunnel, the lumen being only sufficiently large for the passage of the bird. On April 5th a nest containing two bluish eggs was found, and on April 19th, we saw an adult pair accompanied by two full-fledged young.

\section{Carpodectes nitidus Salvin. SNOWy Cotinga.}

This beautiful bird is so rare that even a sight of it is an exciting experience. The species was observed on three separate occasions, but always high in the trees. We first saw two white males and a single female flying about the tops of some forest giants in a bit of pasture jungle about a mile south of 
Guápiles. We next saw two males and two females under similar circumstances up the slope of Turrialba. One morning while sitting at breakfast, a snowy bird was observed crossing behind the house. We at once went outside and were rewarded by seeing five more adult males fly across singly and join the first in the top of an isolated tree in the garden. There were no females and the flock soon made off silently. We did not see them again nor could we find a nearby fruit tree in which they might have been feeding.

\section{Manacus candei (Parzudaki). CANDE MANAKIN.}

On April 15th, while following a tramway up the slope about two miles north of Guápiles, a loud snapping noise was heard emanating from the bush. It was a curiously familiar sound and seemed worthy of investigation. On penetrating the tangled underbrush for a hundred feet or so, a tiny glade was disclosed, about which a number of brilliant black, white and yellow birds were flitting. As soon as one perched for a second, it was recognized as Manacus candei. There were about twenty in the flock, the sexes approximately even. All were moving actively through the bushes, feeding on insects. Often a sombre green female would emit the single shrill call-note, which would be answered by several males. The males, besides the call note, snapped their beaks frequently, making a sharp sound, audible at a considerable distance. They also made a crackling noise, which seemed to be a very rapid series of beak-snappings. This was sometimes followed by a curious, deep grunting note.

The males pursued each other incessantly, moving in short, swift flights accompanied by a loud buzzing sound made by the emarginated outer primaries.

Very often during a period of several weeks the birds were observed in the same locality. They were never seen more than two hundred or three hundred yards from their favorite glade, and were never seen on the west side of the tramway. There was no water there, and nothing seemed to distinguish the spot from the surrounding jungle.

One male examined was in breeding condition. The stomach contained the remains of some small fruit, as well as the hard parts of insects. 


\section{Tyrannus tyrannus (Linn.). KINGBIRD.}

While there are few records of the occurrence of this species in Costa Rica, Carriker ${ }^{1}$ says it is not uncommon there as a winter visitor.

On April 19th, we saw a flock of several hundreds of these birds near Guápiles. Some small, winged insects of which we could not secure a specimen, were swarming, and the Kingbirds were dividing their attention between these and the small, purplish berries of a nearby tree. For more than a week, the flock stayed in the vicinity, feeding much on small fruits. They were silent, even on the frequent occasion of clashes with other flycatchers, especially Pitangus and Myiozetetes, in which they seemed well able to hold their own.

Planesticus grayi casius (Bonap.). Bonaparte TAWny RoBin.

This bird certainly is the finest songster of the Caribbean lowlands. It is abundant about Guápiles where its beautiful song is a characteristic feature. It sings usually early in the morning and late in the afternoon. During the breeding season, there are few moments at these periods of the day when at least one bird cannot be heard.

We found many nests of this species, the first one on April 7th. The favorite site is in the fork of the trees composing the "live fences." As the shoots grow up about the original post, they form a perfect basket, with the top of the post for a bottom. This soon becomes covered with mosses, lichens, and various ferns and parasites, so that it is possible to hide a nest perfectly. The nests are made of mud, moss and lichens, and lined with rootlets. The five or six nests we found each contained two eggs or young birds. The eggs are pale bluish, heavily spotted with chestnut.

\section{Psilorhinus mexicanus cyanogenys (Sharpe). CENTRAL} AMERICAN BROWN JAY.

This species was abundant in the more open parts of the forest and about the potreros. It was seen almost invariably in company with Gymnostinops montezumae, the two species

${ }^{1}$ An Annotated List of the Birds of Costa Rica, including Cocos Island, p. 687 . 
uniting in good-sized flocks which searched the woodland for anything edible. The Jays seemed to act as sentinals for the rather stupid Caciques, giving their shrill alarm notes at the slightest sign of danger. It is of interest to note that a similar association of a Jay and a Cacique, both of different species from the ones here mentioned, has been recorded from British Guiana, by Mr. C. Wm. Beebe. ${ }^{1}$

As the Jays were calling, an audible popping noise could be distinguished, following the note. Careful observation showed a distension on the fore-neck, which was alternately inflated and collapsed, the cracking sound occurring at the point of greatest inflation. Examination of a freshly killed bird disclosed a sac of skin at a point just anterior to the point of the sternum. It was quite flat and measured $14 \mathrm{~mm}$ in length.

A captive specimen of Psilorhinus morio morio (Wagl.) in the Zoological Park exhibited a similar character. This bird never uttered a vocal note, but distended the cervical sac whenever he was excited, making a popping sound which could be heard at a distance of several yards. On examination of this bird after death, the sac was found lying between the branches of the furculum, $1 \mathrm{~mm}$. anterior to their point of union. Deflated, it measured $13 \mathrm{~mm}$. from base to tip and $19.5 \mathrm{~mm}$. along the base, the tip being rounded. Dissection showed this protusion to have been formed by a simple evagination of the dermal covering of the neck. A narrow band of muscle fibres lying in the skin surrounded the base of the sac, but as these bands occur in closely allied forms (as Cyanocitta cristata) it is doubtful if they perform a special function in this case. The sac communicated directly with the praebronchial or interclavicular air-sac (Saccus interclavicularis), through a large opening in the furcular membrane, and doubtless received its air from this source.

Seirus noveboracensis noveboracensis (Gmel.). NORTHERN

\section{WATER-THRUSH.}

One living specimen was taken on April 9th and a second on the 15th. Two others were noticed during the same period.

${ }^{1}$ Our Search for a Wilderness, p. 174. 


\section{Cassidix oryzivora mexicana (?) (Less.). MexiCAN RICE}

\section{GRACKLE.}

Cassidix oryzivora is a rare species in Costa Rica, there being but two authentic records of its occurrence, and one of these is rather obscure. ${ }^{1}$ There is some doubt as to the formi to which Costa Rican specimens should be referred, so mexicana is used advisedly.

On April 26th, while examining, nests of Zarhynchus wagleri wagleri, one was found containing two young birds about two weeks old. One differed markedly from the other, and proved to be a Cassidix.

Dr. Emil A. Goeldi ${ }^{2}$ has described the parasitic habits of C. oryzivora oryzivora of Brazil, which deposits its eggs in the nests of Cacicus persicus, which is the common Cacique there. Zarhynchus is the only Cacique nesting in colonies in the higher parts of Costa Rica, and it is not remarkable that Cassidix should adopt this species for rearing its young.

The feathers of the young bird were quite black, the legs and feet also black, iris dark hazel. The beak and bare portions of the face, including the lores, space in front of the eyes and base of the beak, which were bare of feathers, entirely white. The gape was pale yellow. The bird exhibited the greedy habits usual in parasites and soon was able to care for itself and was brought safely to the Zoological Park.

On May 25th, faint signs of dark coloring were observed in the beak. These gradually increased, so that the change to the pure black of the adult was seen to be under way. The chief points of color increase were at each side of base and tip of both mandibles, although the patches were very irregular.

On June 25, it was noted that the anterior portions of the face and the lores were covered with pin-feathers, which soon clothed these parts. The bill was now much darker, the white tracts being greatly restricted. By August 10, the change was practically complete, only faint traces of white at the tip of the upper mandible remaining.

It is not possible to determine the particular subspecies to which this bird is referable until it becomes adult.

1 Carriker. List of the Birds of Costa Rica, p. 832.

${ }^{2}$ Ibis, Vol. III. Ninth Series, 1897, pp. 361-365. 


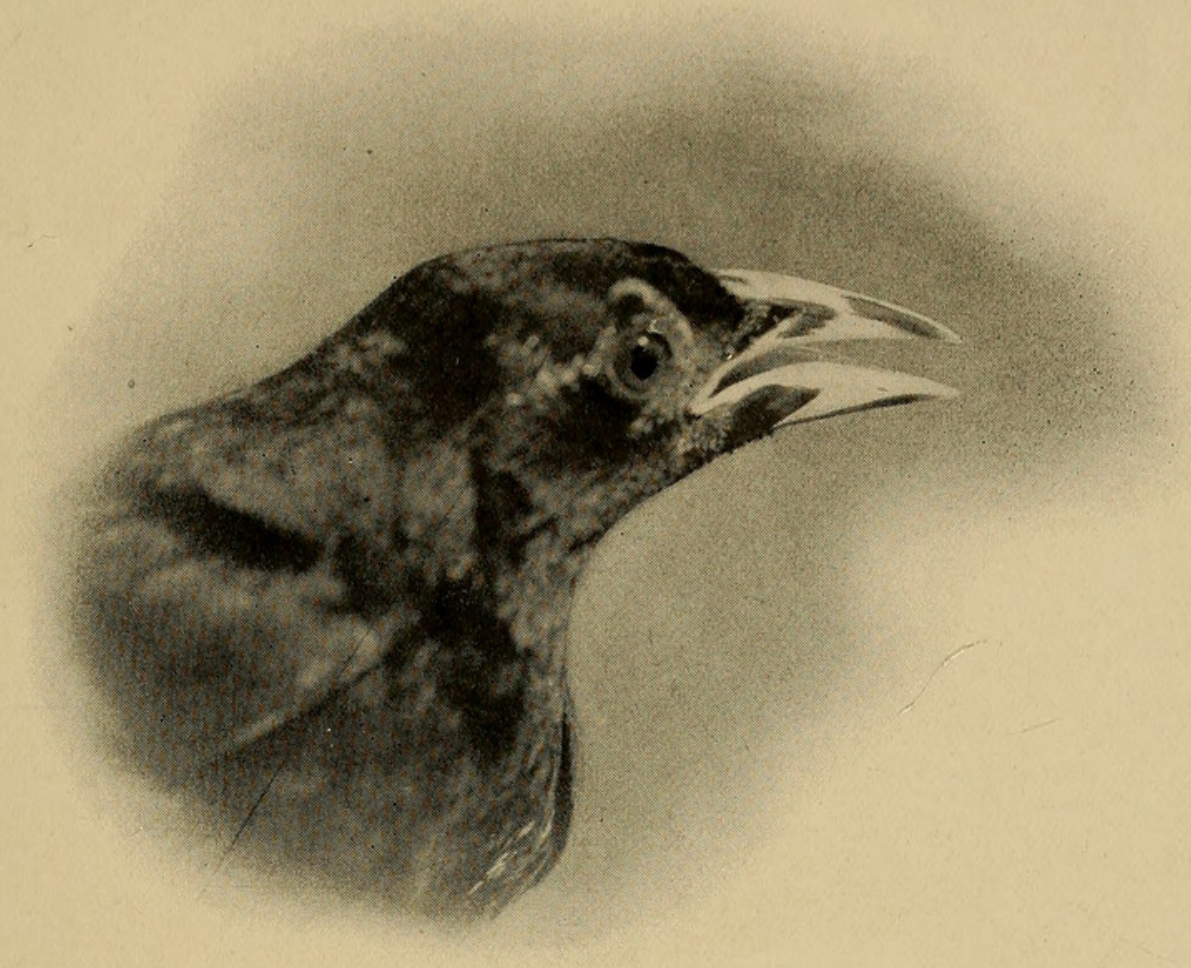

FIG. 113. June 25, 1914.

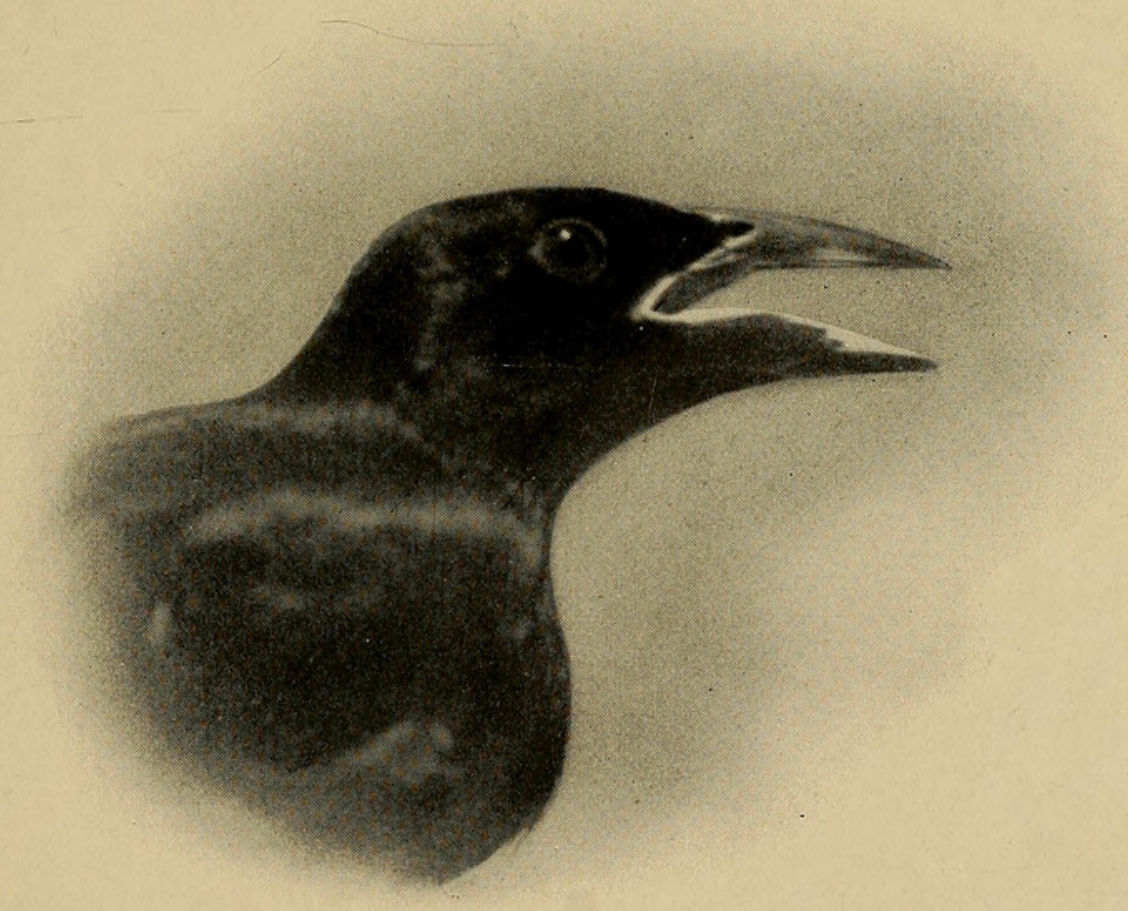

FIG. 114. July 25, 1914.

INCREASE OF PIGMENT IN THE BEAK OF CASSIDIX ORYZIVORA MEXICANA (Less). 
On May 5th, while inspecting the nests of a colony of Gymnostinops montezuma, a recently hatched bird was found in company with a young Gymnostinops. This nestling's skin was white, with occipital, humeral, dorsal and lateral tracts, as well as a slight scattering on the thighs, well covered with long, dark gray down. The beak was white and the gape wide and yellowish. It was in striking contrast with its blackish, downless nest-mate and was no doubt a young Cassidix. Its behavior was quite in contrast to that of Gymnostinops, which shrunk to the bottom of the nest when disturbed, while the young interloper gaped eagerly for food. The two birds were of approximately the same size and equally well nourished. They could not have been more than two or three days old.

In a second nest was found an egg of Gymnostinops accompanied by another (Fig. 116) of quite different appearance. This egg is spotless white, rough in texture and slightly glossed. It measures $36.1 \mathrm{~mm} \times 26.0 \mathrm{~mm}$, which approximates the dimensions of two eggs of Cassidix oryzivora oryzivora in the collection of the British Museum, ${ }^{1}$ and substantiates the belief that the present specimen is referable to C. oryzivora mexicana. It is of interest to note that the egg of Gymnostinops montezuma was addled and evidently deserted, while its fellow was quite fresh.

It is remarkable that with three separate evidences of the presence of Cassidix, not one adult bird was observed, although much time was spent in observation of colonies of both Gymnostinops and Zarhynchus. Carriker? records that in several years of collecting in Costa Rica, he saw but a single specimen of Cassidix, and this one at Guápiles. This bird was referred to $C$. oryzivora mexicana.

\section{Gymnostinops montezuma (Less.). Montezuma Giant}

\section{Cacique.}

This Oropendula apparently is the most abundant Icterine bird of the Caribbean lowlands. Its colonies are of frequent occurrence and the birds, often in company with Psilorhinus. mexicanus cyanogenys, are almost ubiquitous. They were p. 372 .

${ }^{1}$ Catalogue of the Collection of Eggs in the British Museum. Vol. V,

${ }^{2}$ Birds of Costa Rica, etc., p.. 832 . 
breeding at many points about Guápiles, affording an excellent opportunity for observation.

The tree most commonly used by the Caciques is known locally as the Ceiba. The trunk is smooth, with very thin bark, which affords no hold for tree-climbing animals, and rises to a great height before any branches spring out. The base is reinforced by wide-spreading buttresses. The trees selected are usually isolated and the majority are in open potreros or in similar locations, although occasionally they are in open forest. It was noted, however, that the branches are never in contact with those of neighboring trees.

The nests (Fig. 115) vary in number, from half a dozen to as many as 100 . Not more than one-third of the nests in any colony examined were in use, and the occupied nests could be distinguished by their fresher appearance. It seems to be evident that nests once used are seldom if ever repaired, the birds usually building new nests, clustered in another part of the tree.

In only two cases among the many colonies observed, was there evidence of association with wasps, the birds seeming to depend for protection on the great height of the trees.

The nests are in the form of pendulous sacks, the opening being at the top, which is not domed as in Cacious persicus. The length of the many examples measured varied from thirty to forty-eight inches, the average being about thirty-six inches. The diameter of the more globular lower portions averaged nine inches. In all cases, they were built chiefly of the aerial rootlets of various tree parasites, mixed with coarser, weed-like material and here and there a spray of Spanish Moss. The weaving is rather coarse, and the nest in general is not nearly so fine as that of Zarhynchus wagleri. The nests contain a mass of broken dried leaves, to a depth of two or three inches, which form a cushion at the bottom.

In all, the nests of three separate colonies of Gymnostinops were examined. The first, on April 29, consisted of nine nests of which but three were in use. Each contained a single youngster about one-half grown. In the second, on May 5, there were forty-nine nests, of which fifteen were occupied. Fourteen contained young in all stages from newly hatched chicks to nearly 


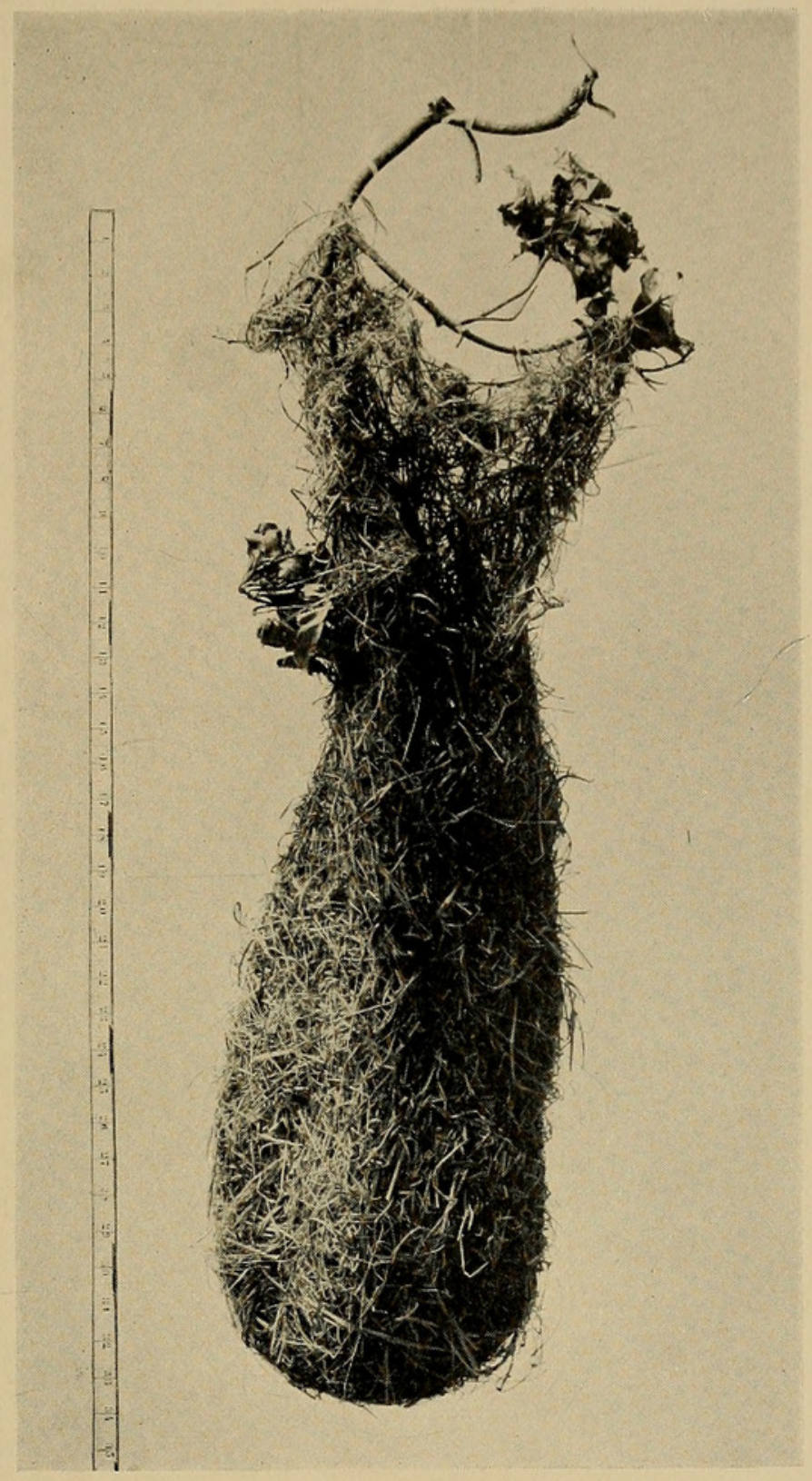

FIG. 115. NEST OF GYMNOSTINOPS MONTEZUMA.

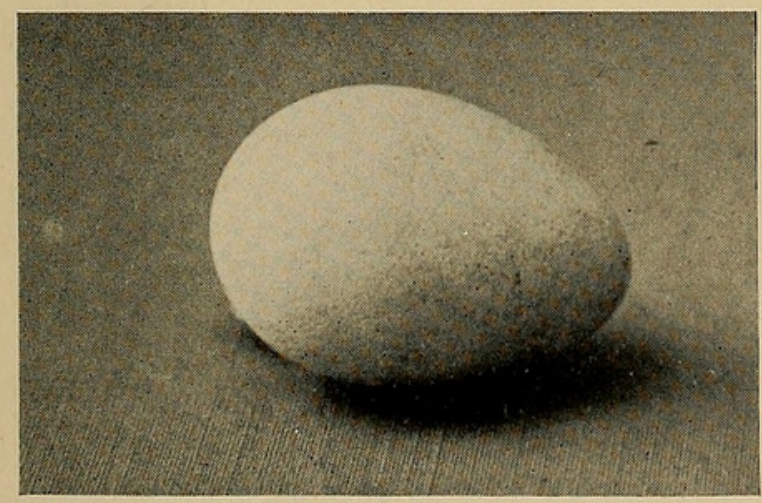

FIG. 116. EGG OF CASSIDIX ORYZIVORA MEXICANA.

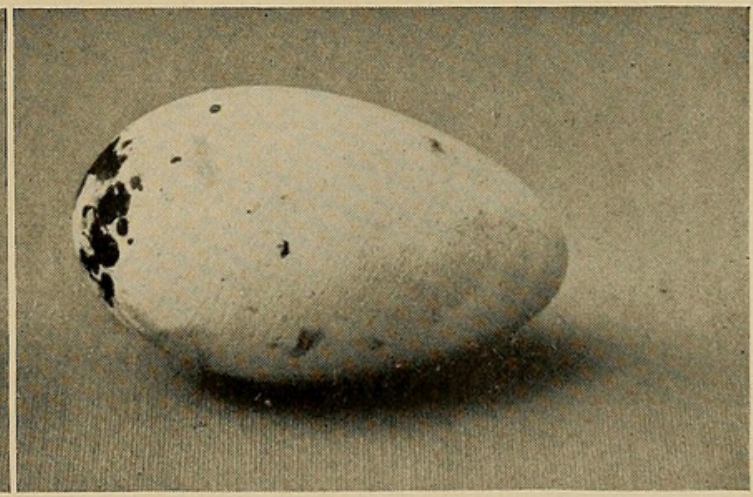

FIG. 117. EGG OF GYMNOSTINOPS MONTEZUMA. 
fledged birds, while one contained the two eggs mentioned under Cassidix. In only one case did a nest contain two young Gymnostinops, while a Cassidix shared another with the single rightful inmate. The third colony, also examined on May 5, was one of nineteen nests. Only three were occupied, each containing a nearly fledged young bird. It seems probable that other young had flown, as some of the nests showed signs of recent occupancy.

It will thus be seen that of twenty-one nests containing young or eggs, in only one instance was there more than one occupant. It seems evident, then, that the normal complement of this species is but a single egg.

The egg collected measures $42.4 \times 25.1 \mathrm{~mm}$., seeming to be rather abnormal as to length (Fig. 117). It is a very pale bluish white, lightly spotted throughout, but heavily encircled at the larger end with chocolate blotches.

The newly hatched chicks are blackish, the skin leathery and shiny, and quite devoid of down. The beak is black, with both mandibles tipped with yellow, the gape being pale yellow.

The stomach of one young bird examined was crammed with insect remains and fruit seeds. Several very large locusts were represented, the bird apparently not being inconvenienced by the huge tibial spines.

The food of the adults is evidently of a highly varied character. Many kinds of fruits and berries enter into it, as well as such animal food as they chance to come across. Birds were observed carrying locusts, roaches and other insects to the young, and on one occasion a freshly-killed mouse was found in a nest. A dead frog given to a captive specimen was seized and passed to and fro in the great beak. The frog was then held down with one foot, Jay fashion, and each leg carefully broken, when it was swallowed without further ado.

The notes and display of the male Gymnostinops have been described too often to be repeated here. It was noted, however, that the male often flew against a nest with great force, so that it swung about wildly, and that the curious gymnastic performances were executed while the bird hung sideways in this perilous position. 
Zarhynchus wagleri wagleri (Gray). WAgLER GIANT CACIQUE.

This species is found only in the highlands and usually is not found below 2,000 feet. A tramway runs from Guápiles up the slope of Turrialba for about six miles. About four miles up, at an estimated altitude of 1,800 feet, was a large colony of $Z$ arhynchus, and farther on a smaller one.

The trees in these cases were not of the species chosen by Gymnostinops. They were less tall, narrower in girth and with the small branches covered with spines. Neither colony was associated with wasps.

The visit was made on April 26. The smaller group numbered twenty-one nests, the other forty-three, a total of sixtyfour. Of these, but thirty-nine were occupied. Twenty-two contained eggs and seventeen held young in all stages of development. Of the latter one held two nearly fledged young, beside the nest which was shared with a Cassidix, and two others two small birds each, while two contained pairs of eggs. Thus, out of a total of thirty-nine occupied nests, only five contained more than one egg or chick. It seems, therefore, that the normal clutch of this species, as well as Gymnostinops, is but one egg.

The measurements of six eggs collected are as follows:

$32 \mathrm{~mm} . \times 22.65 \mathrm{~mm}$.

$32.55 \mathrm{~mm}$. $\mathrm{x} 22.2 \mathrm{~mm}$.

$34.5 \mathrm{~mm}$. x $23 \mathrm{~mm}$.
$32.9 \mathrm{~mm}$. x $22 \mathrm{~mm}$.

$33.3 \mathrm{~mm} . \times 22.6 \mathrm{~mm}$.

$34.2 \mathrm{~mm} \times 22.7 \mathrm{~mm}$.

They are pale greenish blue, blotched with dark brown, more heavily at the larger end. yellow.

The young have the beak quite white and the gape pale

The nests of Zarhynchus were composed of the same materials as were those of the larger species but, as would be expected, the former are considerably smaller. Many were measured, and all were between twenty-four and thirty inches in length, the average being about twenty-eight inches, while the diameter at the bottom averaged seven inches. The weave is much closer and finer, and the nests of the two species are dis- 
tinguishable at a glance by this character alone. They were lined with bits of long, narrow leaves, some still green, of a different species from those used by Gymnostinops. They may have possessed some quality unpleasant to bird lice, for while the nests of Gymnostinops were infested with them, there were none in those of the present species.

\section{Rhamphocoelus passerinii Bonap. PASSERINI SILver-BeAK}

\section{TANAGER.}

The most casual traveler in Costa Rica cannot but be impressed by the remarkable conspicuousness of this common bird. It is abundant everywhere, and the flashing scarlet of its lower back can be seen at a considerable distance. Very often the wings are drawn down so that the red patch is exposed to its fullest extent, and a more patent signal to passing birds of prey could hardly be imagined. Its very evident success in life can be explained only by its habit of living in the vicinity of thick bushes, into the depths of which it darts when danger threatens.

Arremonops conirostris richmondi Ridg. RICHMOND SPARROW.

This is one of the most abundant birds about Guápiles. It has a great variety of queer notes, its chug-chug-chug being characteristic of the potreros.

Nests were found frequently. They were placed close to the ground in a clump of weeds or grasses, in open places. They were built of coarse dried grasses and roots, domed, and with the entrance at the side. One found on April 6 contained two newly-hatched chicks, an unusually early date. The eggs are plain white, usually four in number. 


\section{$2 \mathrm{BHL}$ Biodiversity Heritage Library}

Crandall, Lee S. 1914. "Notes on Costa Rican birds." Zoologica : scientific contributions of the New York Zoological Society 1(18), 325-343. https://doi.org/10.5962/p.203803.

View This Item Online: $\underline{\text { https://www.biodiversitylibrary.org/item/97326 }}$

DOI: https://doi.org/10.5962/p.203803

Permalink: https://www.biodiversitylibrary.org/partpdf/203803

\section{Holding Institution}

Harvard University, Museum of Comparative Zoology, Ernst Mayr Library

\section{Sponsored by}

Harvard University, Museum of Comparative Zoology, Ernst Mayr Library

\section{Copyright \& Reuse}

Copyright Status: Public domain. The BHL considers that this work is no longer under copyright protection.

This document was created from content at the Biodiversity Heritage Library, the world's largest open access digital library for biodiversity literature and archives. Visit BHL at https://www.biodiversitylibrary.org. 